\title{
Deformation of the Cape Chignecto Pluton, Cobequid Highlands, Nova Scotia: thrusting at the Meguma-Avalon boundary
}

\author{
John W.F. Waldron \\ Department of Geology, St. Mary's University, Halifax, Nova Scotia B3H 3C3, Canada
}

\author{
David J.W. Piper \\ Atlantic Geoscience Centre, Geological Survey of Canada, Bedford Institute of Oceanography \\ P.O. Box 1006, Dartmouth, Nova Scotia B2Y 4A2, Canada
}

and

\author{
Georgia Pe-Piper \\ Department of Geology, St. Mary's University, Halifax, Nova Scotia B3H 3C3, Canada
}

Date Received May 25, 1988
Date Accepted May 30, 1989

The Early Carboniferous Cape Chignecto pluton, at the western end of the Cobequid Highlands in the Avalon Terrane of Nova Scotia, consists predominantly of two-feldspar biotite granite. Intrusion of smaller diorite bodies locally melted and hybridized the granite. Diabase and microgranite dykes cut the plutons.

Much of the pluton has a flat-lying mylonitic foliation, with a mineral elongation lineation trending between north and west. Quartz is dynamically recrystallized, but feldspars show predominantly brittle deformation. The pluton was probably deformed under greenschist facies conditions, after cooling. C-S fabrics observed in the field, and tails on porphyroclasts seen in thin section, indicate northward overthrusting. The Hadrynian Jeffers Group is thrust over the south edge of the pluton in the Fowler Brook inlier. At its north edge, the pluton is probably thrust over volcanic rocks of the Fountain Lake Group. The deformation of the pluton is constrained by stratigraphic relationships and isotopic dates to a Namurian or possibly early Westphalian age.

Deformation within the pluton is correlated with Namurian uplift of the Cobequid and Caledonia Highlands. It records either transpression resulting from the curvature of the Meguma-Avalon boundary or a major component of convergent movement between the Meguma and Avalon terranes.

Le pluton de Cape Chignecto, daté du début du Carbonifere et situé à l'extrémité occidentale des Monts Cobequid (Lanière d'Avalon, Nouvelle-Ecosse), est formé en majeure partie de granite à biotite à deux feldspaths. Le granite subit une fonte et une hybridation locales lors de l'intrusion de bâtis dioritiques de plus faibles dimensions. Des dykes de diabase et de microgranite recoupent les plutons.

La majeure partie du pluton présente une foliation mylonitique horizontale, avec une linéation d'étirement orientée entre le nord et l'ouest. On note une recristallisation dynamique du quartz mais la déformation des feldspaths est surtout fragile. Le pluton fut probablement déformé sous des conditions appartenant au faciès des schistes verts, et ce après son refroidissement. Des fabriques planaires C-S, observées sur le terrain, et des ombres de pression dissymétriques, vues en lame mince, indiquent un charriage vers le nord. Le Groupe hadrynien de Jeffers chevauche l'extrémité méridionale du pluton dans la fenêtre de Fowler Brook. A son extrémité septentrionale, le pluton chevauche probablement les volcanites du Groupe de Fountain Lake. Les relations stratigraphiques et des datations radiométriques limitent l'âge de la déformation du pluton au Namurien ou possiblement au début du Westphalien.

On corrèle la déformation au sein du pluton avec la surrection namurienne des monts Cobequid et Caledonia. Cette déformation enregistre soit une transpression résultant de la cambrure de la jonction Meguma-Avalon, soit une forte composante de mouvement convergent entre les lanières de Meguma et d'Avalon.

[Traduit par le joumal] 


\section{INTRODUCTION}

\section{Regional Geological Setting}

The Cape Chignecto pluton (Figs. 1,2) is one of a series of Early Carboniferous granites located immediately north of the Cobequid Fault in the western Cobequid Highlands (Donohoe and Wallace, 1982, 1985; Pe-Piper et al., in press). The granite in much of the pluton has a flat-lying mylonitic fabric (Donohoe and Wallace, 1985). The pluton is in tectonic contact with the late Hadrynian Jeffers Group and the volcanic rocks of the Fountain Lake Group (of uncertain age, but dated as Early Carboniferous $50 \mathrm{~km}$ east in the Parrsboro area). It is overlain unconformably by the Early Carboniferous Rapid Brook Formation (Donohoe and Wallace, 1985). To the south, the pluton appears to be cut by the Cobequid Fault zone.

The Cape Chignecto pluton consists principally of subsolvus biotite granite. A series of thick diorite bodies intrude the southwestern part of the pluton (mapped separately as the Soldier Brook Diorite by Donohoe and Wallace, 1982); we have observed interleaving of granite and diorite on a variety of scales but have not attempted to map individual diorite bodies. Similar granites and diorites occur in the Fowler Brook inlier $10 \mathrm{~km}$ to the east, previously mapped by Donohoe and Wallace as the Apple River pluton (Fig. 2). Because of their petrologic and structural similarity to the main Cape Chignecto outcrops, Pe-Piper $e t$ al. (in press) regard these bodies of granite and diorite as parts of the Cape Chignecto pluton, and this usage is followed in this paper.

The Cape Chignecto pluton is one of a series of Early Carboniferous granite plutons found just north of the Cobequid Fault (Fig. 2). These plutons include minor diorite phases, and have similar geochemistry, including trace element abundances typical of extensional within-plate tectonic environments (PePiper $e t$ al., in press).

The Early Carboniferous Fountain Lake Group basalts and rhyolites cropping out between the Hanna Farm and North River plutons are geochemically similar to the intrusive rocks and are interpreted as extrusive products of the same magmatism (PePiper $e t$ al., in press). Fountain Lake Group volcanic rocks crop out immediately north of the Cape Chignecto pluton (Figs. 2,3): the age of these rocks is not known. In the eastem Cobequid Highlands, the age of the Fountain Lake Group ranges from Late Devonian to Early Carboniferous (Donohoe and Wallace, 1985; Donohoe et al., 1986; Pe-Piper et al., in press).

The Early Carboniferous Rapid Brook Formation (conglomerate, sandstone, siltstone) unconformably overlies the Cape Chignecto pluton, and contains clasts of granite similar to that of the pluton. The overlying Greville River Formation comprises siltstone and minor sandstone and contains plant fossils of Carboniferous age. Both formations are deformed into upright to inclined folds with local development of a penetrative cleavage, and are cut by northeast and northwest-striking faults (Donohoe and Wallace, 1985). Unconformable relationships elsewhere along the Cobequid Fault zone suggest that this deformation and faulting are of Namurian to Westphalian B age (330 to $310 \mathrm{Ma}$ ) (Donohoe and Wallace, 1985).

\section{Regional Correlations}

Magmatism and deformation of Carboniferous age are widespread in the Avalon terrane of Nova Scotia and New Brunswick, and have been associated in general terms with the docking of the Avalon and Meguma terranes of the Appalachians (Williams and Hatcher, 1983), and with displacement along the Minas Geofracture (Keppie, 1982). Most of this displacement was by dextral slip (Eisbacher, 1969, 1970; Mawer and Williams, 1986; Mawer and White, 1987; Yeo and Gao, 1987).

The timing of movement on the major faults in the Cobequid Hills is partially constrained by isotopic and stratigraphic data. In the eastern Cobequid Highlands, the Rockland Brook Fault, immediately north of the Cobequid Fault, mylonitized the Hart Lake-Byers Lake pluton (dated at $348 \pm 5 \mathrm{Ma}$ by Donohoe $e t$ al., 1986), but motion had ended by the time of intrusion of the Pleasant Hills pluton, dated at $315 \pm 25 \mathrm{Ma}$ (Cormier, 1979). The Cobequid Fault itself cuts all Carboniferous and early Mesozoic strata, and although the later movement is probably principally dip-slip, there is post-early Jurassic strike slip-motion on the Gerrish Mountain Fault (Fig. 1) (Donohoe and Wallace, 1985).

The supply of coarse detritus northwards from the Cobequid Highlands to the Cumberland Basin has been used by Ryan et al. (1987) to identify times of uplift in the region. They recognized three major periods of uplift, in the mid-Devonian, the Late Namurian (marked by the Millsville conglomerate) and the Westphalian B (marked by basal Cumberland Group conglomerates).

Widespread thrust deformation of mid-Carboniferous (Westphalian B-C) age has been identified in the Saint John area of southern New Brunswick (Nance and Warner, 1987). Plint and van de Poll (1984) inferred Visean motion on the Quaco Head Fault, Namurian uplift of the Caledonia Highlands to the north, and thrusting that began in Westphalian B time, but with major movement in post-Westphalian C time.

\section{GEOLOGY OF THE CAPE CHIGNECTO PLUTON}

\section{General Characteristics}

The Cape Chignecto pluton is continuously exposed on the coast, but access is severely limited by steep cliffs and extreme tides. Inland, the pluton is densely wooded, but good exposures are found in streams. This study is based on detailed examinations of accessible portions of the coast, and of inland exposures in streams.

The Cape Chignecto pluton comprises granite, diorite, and various hybrid rocks. The pluton is cut by diabase and microgranite dykes of unknown age. The diorite occurs in bodies of many hundreds of metres total thickness in the southern part of the pluton. Although most granite-diorite contacts are tectonized, some igneous contacts with granite are seen. At these contacts, the diorite is chilled against the granite and locally contains feldspar xenocrysts and xenoliths of granite, many of which show evidence of digestion. Locally, granite dykelets, presumably melted by the hot diorite, have intruded the diorite. 


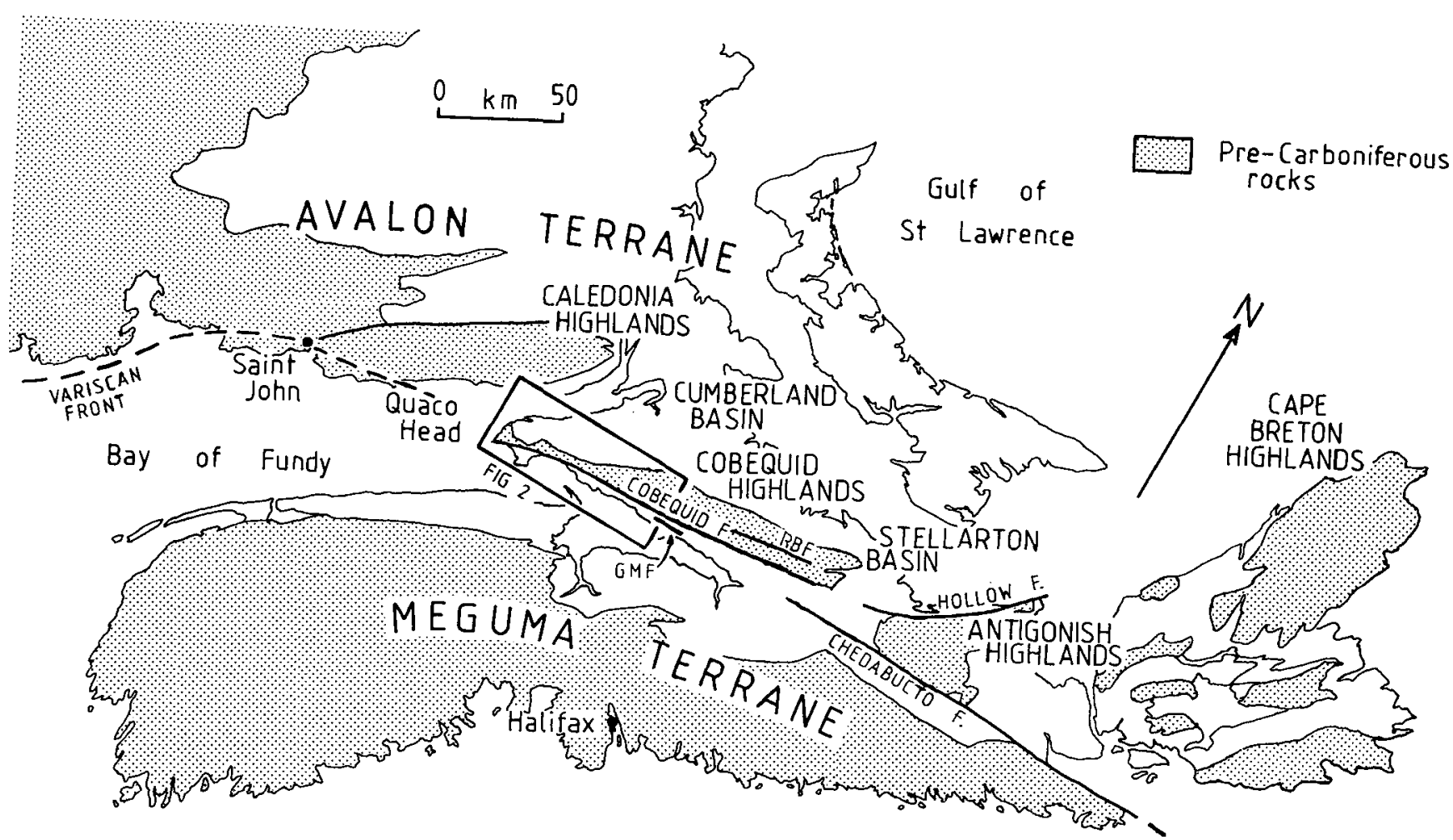

Fig. 1. Map of the Maritime Provinces and adjacent areas of New England showing Appalachian terranes, major faults and regional setting of the Cape Chignecto pluton (based on Williams and Hatcher, 1983, and Hutchinson et al., 1988). Box shows location of Figure 2. RBF - Rockland Brook Fault; GMF - Gerrish Mountain Fault.

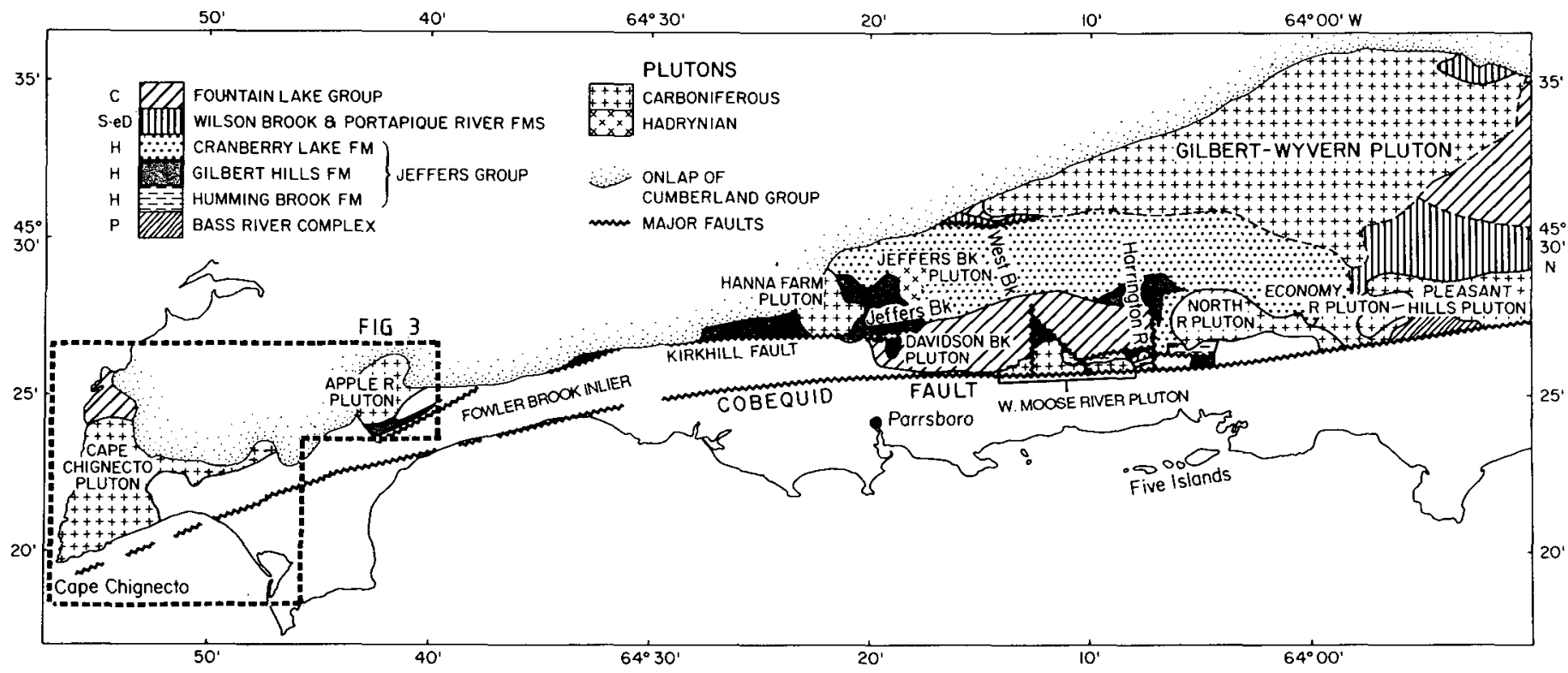

Fig. 2. Geological map of the western Cobequid Highlands showing distribution of Early Carboniferous plutons (from Pe-Piper $e$ t al., in press, based on Donohoe and Wallace, 1982, with modifications). Unpatterned areas: Carboniferous sedimentary rocks, Triassic sedimentary and volcanic rocks. Location shown on Figure 1.

In some places there has been a mixing of the melt phases of granite and diorite to form monzonite and granodiorite.

Many of the granites in Cape Chignecto pluton show red hematitic staining, associated with brittle fractures. Green secondary biotite is found in the same fractures.

Donohoe and Wallace (1982) mapped a belt of Fountain
Lake Group rhyolite extending eastwards from their Cape Chignecto pluton. We have re-examined the rocks in this area; all consist of mylonitized granite. The only Fountain Lake Group in the region crops out along a coastal strip on the northwestern margin of the pluton. 


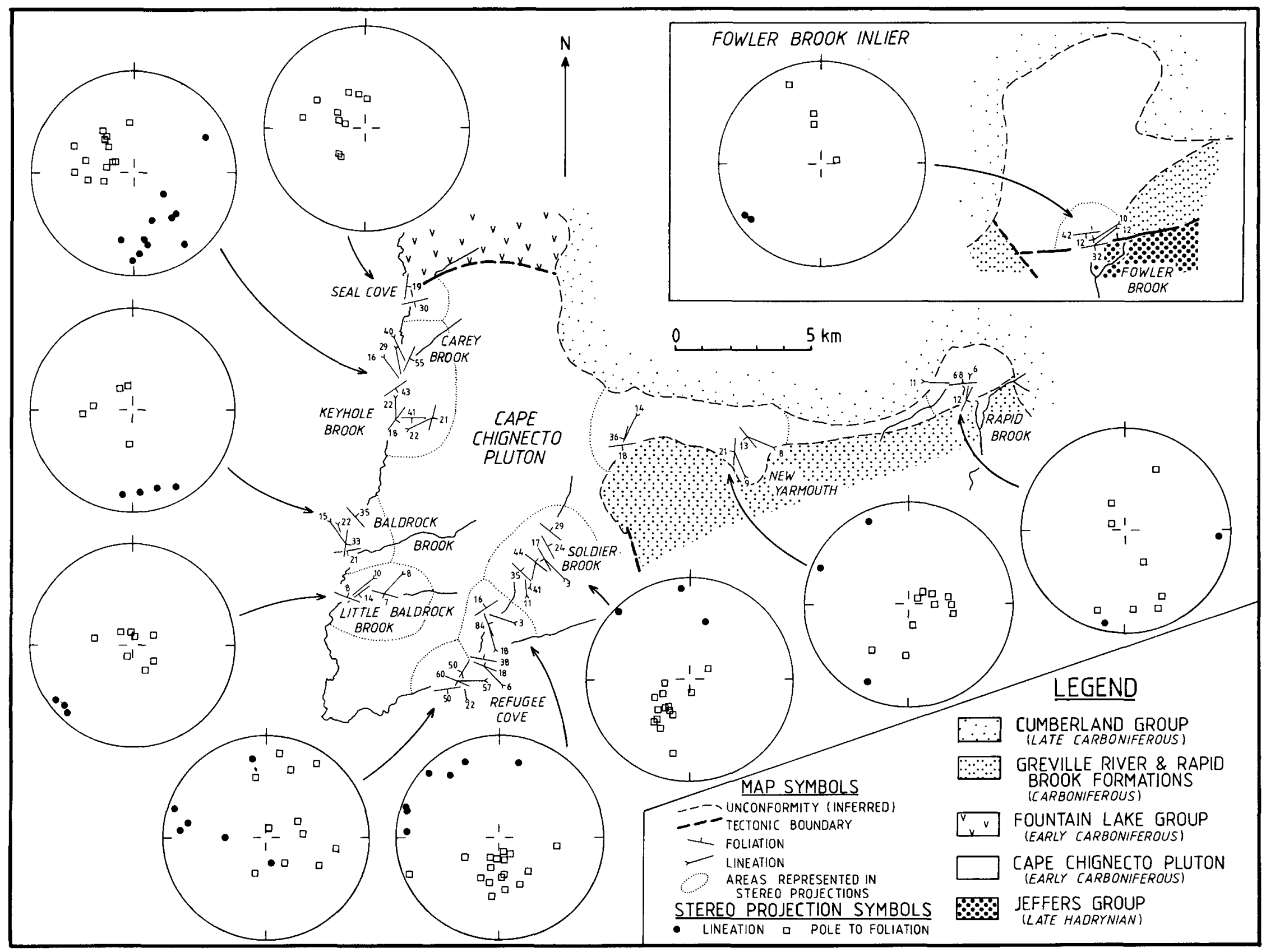

Fig. 3. Map and lower hemisphere equal-area projections showing orientations of mylonitic foliations and elongation lineations from selected areas within the Cape Chignecto pluton. Inset shows Fowler Brook inlier. 
A separate area of deformed granites and diorites (the Apple River pluton of Donohoe and Wallace, 1982) occurs to the northeast of the Cape Chignecto Pluton in the Fowler Brook inlier. Deformed granites and diorites in the Fowler Brook Inlier (Fig. 3) are interpreted as a continuation of the Cape Chignecto pluton. On their southern margin, the plutonic rocks are tectonically overlain by sheared felsic pyroclastic rocks of the Late Hadrynian Jeffers Group. Further south, the inlier is separated from the Carboniferous sediments of the Greville River Formation by a major subvertical cataclastic zone.

\section{Petrography}

Undeformed granite in the Cape Chignecto pluton consists principally of quartz, albite (in perthite and antiperthite), and microcline, with minor allanite, brown biotite and zircon. Some samples show graphic textures. More deformed lithologies show increasing alteration of feldspar to epidote. The primary brown biotite first exsolves rutile and then alters completely to green secondary biotite as degree of deformation increases. Microprobe analysis shows that there is a corresponding progressive decrease in $\mathrm{Ti}$ and increase in the $\mathrm{Mg}$ contents of the biotite.

Undeformed diorite shows a sub-ophitic texture of plagioclase, hornblende (locally actinolite) and brown biotite (locally with minor chlorite), with minor quartz, opaque minerals, and $\mathrm{K}$ feldspar, and accessory zircon, apatite, and sphene. With increasing deformation, there is progressively more alteration of both hornblende and brown primary biotite to green secondary biotite, and of plagioclase to aggregates of albite, epidote and sericite. In mylonitic rocks, mafic minerals are concentrated in stringers and veinlets and consist entirely of secondary biotite, with minor epidote in some samples.

Hybrid monzonite and granodiorite have mineralogical compositions intermediate between diorite and granite. Quartz and feldspar are the dominant minerals, but there is a higher porportion of mafic minerals than in the granites.

\section{STRUCTURE}

\section{Fabrics - Field Observations}

The majority of outcrops of the Cape Chignecto pluton show tectonic fabrics, but the intensity and homogeneity of deformation is variable. In the north of the pluton, at Seal Cove and Carey Brook (Fig. 3), weakly developed foliations and lineations are defined by coarse $(5-20 \mathrm{~mm})$ quartz and feldspar-rich domains with typical aspect ratios on exposed surfaces of about 2:1. Discrete, fine-grained shear zones a few millimetres thick show a more intense mylonitic foliation. The granite is cut by sheetlike mafic bodies 0.5 to $5 \mathrm{~m}$ thick. Some of these are steeplydipping late diabase dykes, which are undeformed or show only slight foliation close to their chilled margins. The majority of mafic sheets, however, have dioritic compositions and show a strong foliation sub-parallel to their margins. The foliation is developed both within the sheets and in the immediately adjacent granite. These sheets contain elongated pods and lenses of stretched and foliated granite. Most also show late brecciation.
The orientations of both the shear zones within granite and the mafic sheets are variable, but the majority dip gently to moderately east or southeast and bear southeast-plunging lineations. In cliff exposures south of Carey Brook, the foliated mafic sheets appear to form an anastomosing network with an overall subhorizontal orientation, but within which individual sheets diverge at angles up to $30^{\circ}$ from the mean orientation.

Farther south, between Keyhole and Baldrock brooks (Fig. 3 ), the granite becomes more strongly foliated and lineated. About $300 \mathrm{~m}$ north of the mouth of Baldrock Brook, elongated quartz-filled pods, typically $5 \mathrm{~cm}$ long, show aspect ratios up to 5:1 and define a strong lineation plunging gently south. C-S foliations are locally developed in more homogeneous granite without quartz pods, and indicate northward overthrusting on the subhorizontal to southeast-dipping shear planes (Fig. 4a). The granite south of this locality is cut by more intensely deformed mylonitic shear zones 1 to $10 \mathrm{~cm}$ thick, which locally follow the contacts of mafic sheets up to $5 \mathrm{~m}$ thick. Similar, heterogeneously deformed granite and diorite with gently dipping foliations crop out in Little Baldrock Brook, but lineations there plunge to the SW.

Exposures on the south coast of Cape Chignecto at Refugee Cove and inland at Soldier Brook (Fig. 3) display still more highly foliated plutonic rocks. Deformation has clearly been extremely heterogeneous. Undeformed domains up to several metres across show complex primary intrusive relationships, with granite dykes intruding mafic rocks (Fig. 4b), and mafic rocks assimilating earlier granite. Towards the margins of these domains, igneous relationships become progressively obscured as pink feldspar grains derived from the partially assimilated granite are isolated as augen within foliated mafic phyllites, and granite dykes are transposed (Fig. 4c) into orientations subparallel to the overall foliation of the surrounding mylonitic rocks (which here dips north). Oblique foliations asymptotic to the highly sheared zones again indicate that overlying rocks were transported to the north or northwest. The trends of observed stretching lineations vary between NNE and WNW. Immediately east of Refugee Cove these heterogeneous rocks are overlain by a north-dipping sheet of more homogeneous foliated granite about $20 \mathrm{~m}$ thick, enclosing only occasional lenses (up to $50 \mathrm{~cm}$ thick) of either foliated mafic material or undeformed granite. This sheet is in turn overlain by more hybrid deformed intrusives.

West of Refugee Cove, relationships are more complex. A major zone of brittle, ESE-striking faults separates the northwest-dipping foliated intrusive rocks observed at the cove from granites and subordinate mafic rocks in which the foliation dips steeply south. Where observed, lineations on these steep foliation surfaces pitch steeply east or west.

The most highly deformed granites are exposed inland, in a belt partly mapped as Fountain Lake Rhyolite by Donohoe and Wallace (1982), but which includes their New Yarmouth and Fire Tower plutons. Granitic protomylonites, mylonites and flinty ultramylonites show millimetre-scale banding. No lineation is visible in the field in the ultramylonites, but less deformed rocks show strong stretching lineations with trends which again vary between NW and NNE. Similar lithologies occur farther east in 

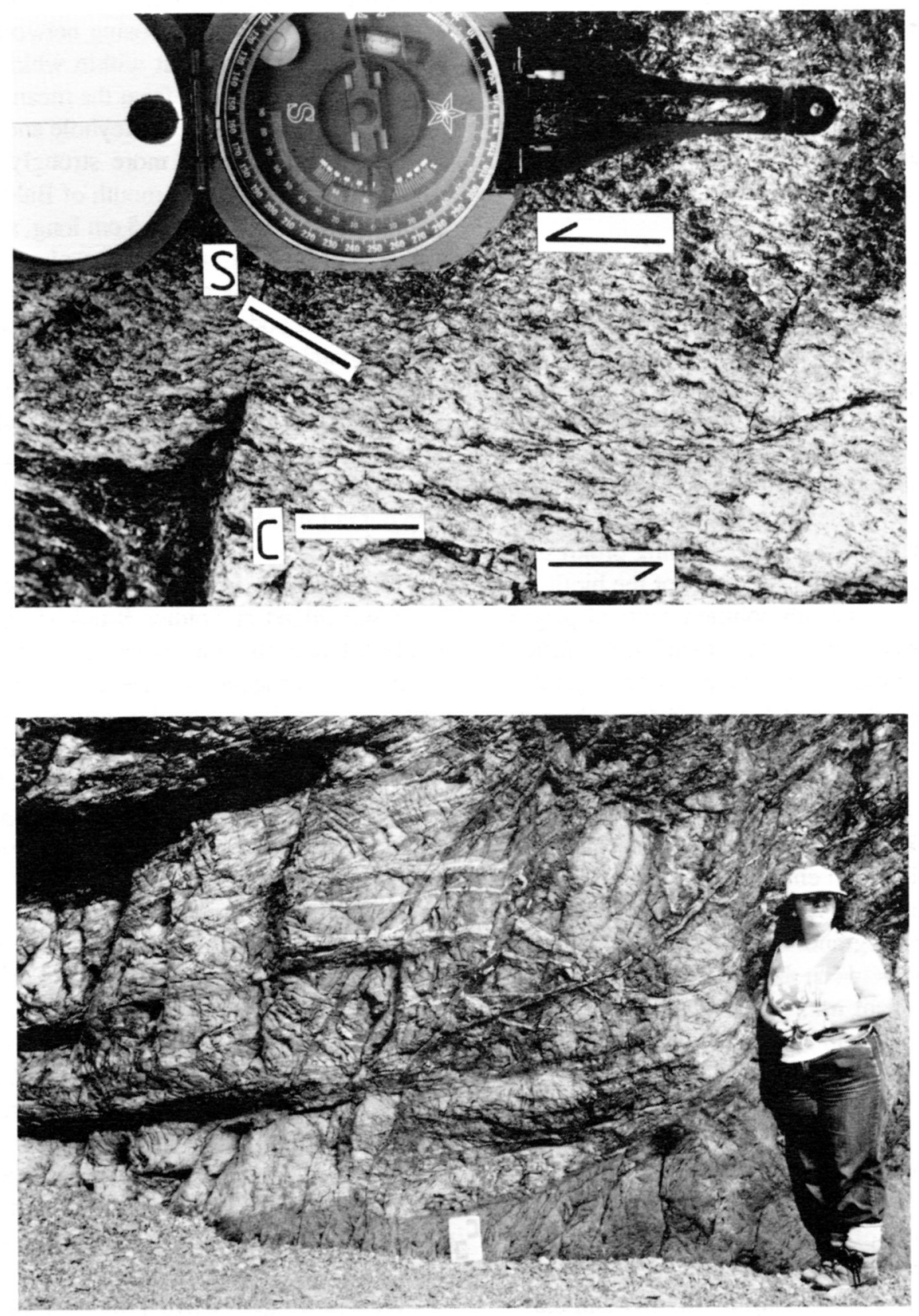

Fig. 4. Field observations and photomicrographs. (a) Deformed granite showing C-S fabric indicating northward overthrusting. Coast, $100 \mathrm{~m}$ north of mouth of Big Baldrock Brook. (b) Relatively undeformed enclave, east side of Refugee Cove, showing granite dykes cutting diorite. Dykes are cut by fault (centre) and transposed (top left) into mylonitic foliation in more sheared zone. (c)Close-up of top edge of enclave in (b) showing folding of granite dyke in mylonitic zone. (d) Photomicrograph of typical protomylonite and mylonite showing single feldspar crystal (between arrows) extended by fracturing into numerous fragments along cleavage surfaces. $2 \mathrm{~km}$ west of New Yarmouth. Scale bar $1 \mathrm{~mm}$ approximately, plane polarized light. (e) Large fractured feldspar porphyroclast (pale, centre) surrounded by finer grained granitic mylonite. New relatively undeformed quartz crystals have grown in the fractures (arrows). New Yarmouth. Scale bar $0.5 \mathrm{~mm}$ approximately, crossed polars. (f) Dynamically recrystallized quartz ribbons. Elongation of individual quartz crystals (short bar) is oblique to overall foliation (long bar), a relationship indicating shear in sense marked. Large porphyroclasts at top left and in dark area at lower right are feldspars. New Yarmouth. Scale bar 0.5 mm approximately, crossed polars. 


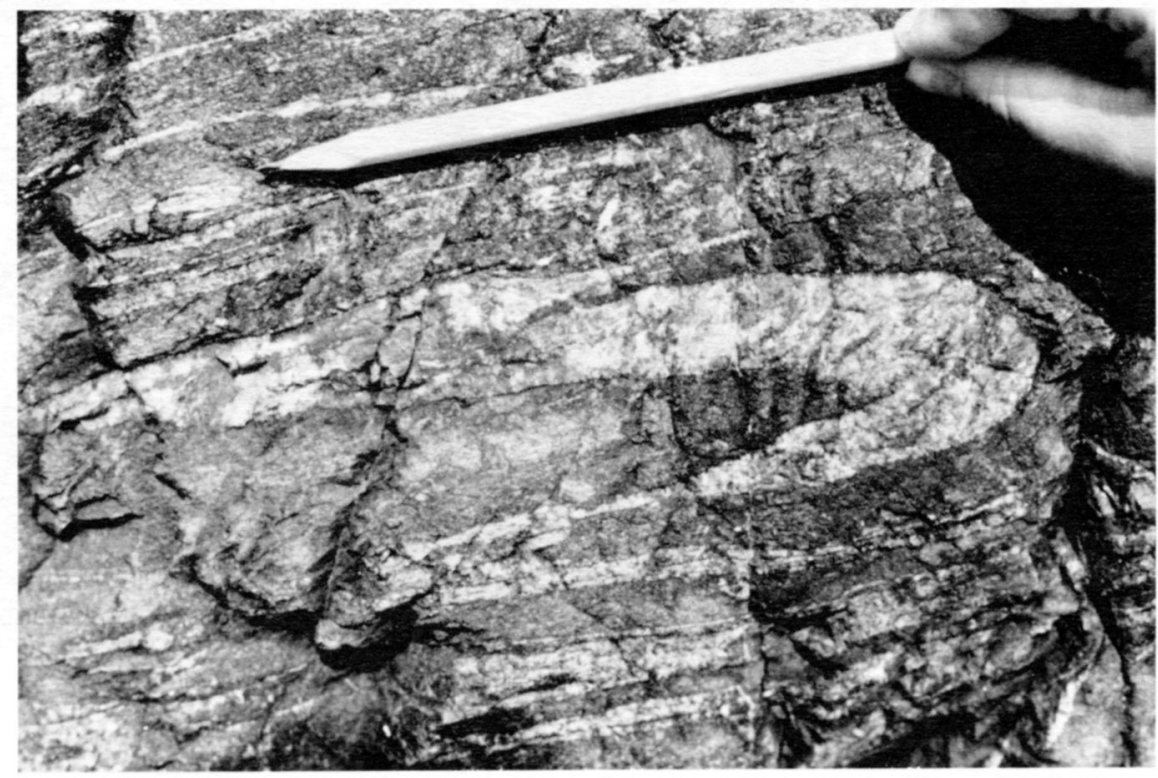

C

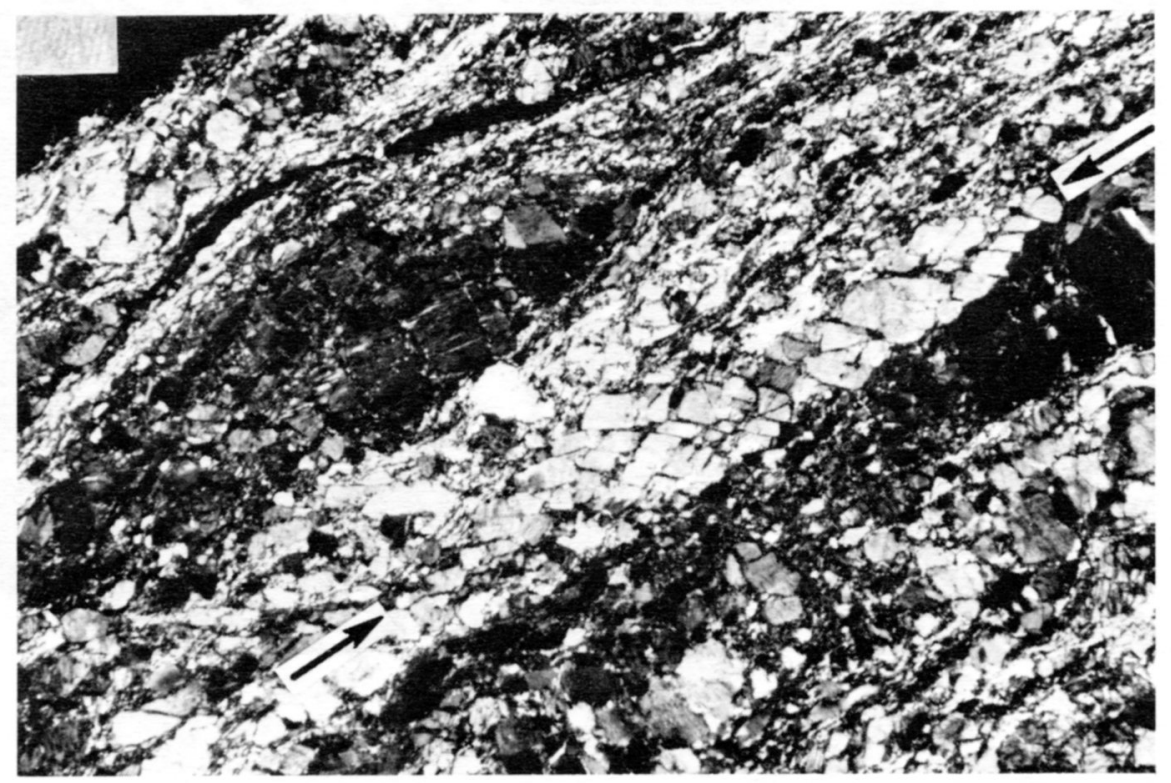

Fig. 4 Cont. 

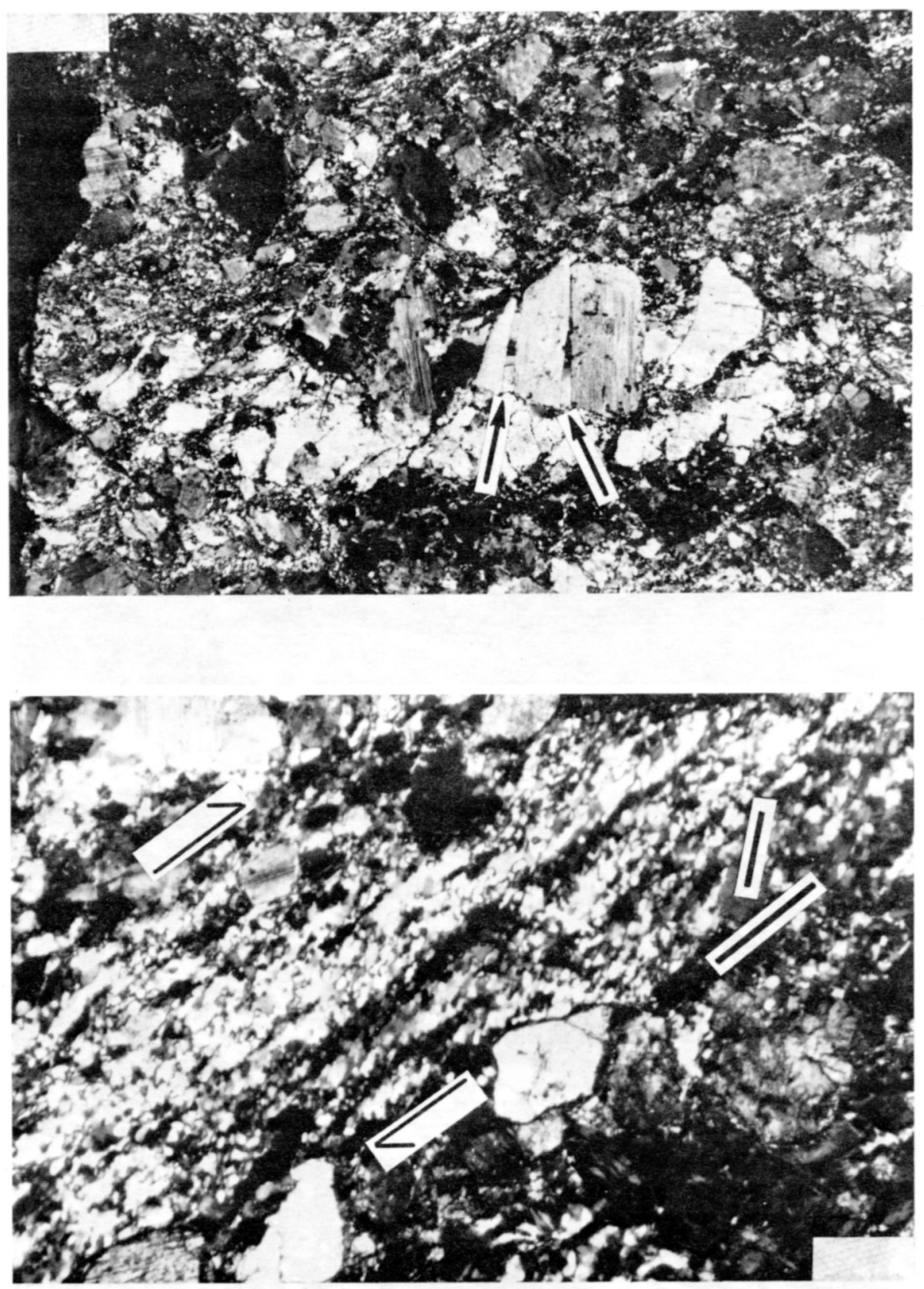

Fig. 4 Cont. 
the poorly exposed plutonic rocks of the Fowler Brook inlier, but there the observed lineations trend SW.

\section{Fabrics - Thin Section}

Even in weakly foliated and lineated granites, the majority of quartz grains are dynamically recrystallized to polygonal aggregates with mean grain sizes in the range 10 to 50 microns. These aggregates show a strong preferred optical orientation. The large pods of quartz at Baldrock Brook, which are only partially recrystallized, show a mortar structure defined by seams of new polygonal grains outlining large plates with distinct subgrains. The feldspars, in contrast, are deformed by fracture and slip along cleavage surfaces, and by detachment of angular cleavage fragments (Fig. 4d, e). Some large plagioclase porphyroclasts are kinked, but there is no major dynamic recrystallisation in feldspar.

In more highly deformed granites, both quartz and feldspar show strongly reduced grain sizes. Feldspars occur as rounded porphyroclasts surrounded by fine-grained, foliated mylonitic matrix with a strong preferred optical orientation.

In foliated and lineated samples of diorite and hybrid rocks primary biotite and hornblende are absent; only green secondary biotite is present. Individual crystals of this green biotite are undeformed, or mildly kinked in some rocks. They are concentrated both along foliation surfaces and along rare brittle fractures at high angles to the foliation, where they are associated with hematite and other opaques. Secondary undeformed epidotealso occurs in deformed granites. Crystallization of these minerals must have been completed after the main ductile deformation; at least some of the mineral growth is of hydrothermal origin.

Thin sections cut parallel to lineations and perpendicular to foliation have been used to determine the sense of shearing. They show that $\mathrm{C}$-S fabrics are defined by inequant feldspar porphyroclasts (defining S-planes) surrounded by stretched and recrystallized quartz. The $\mathrm{C}$-planes appear as discrete fractures or as bands of fine-grained mylonite. In more highly mylonitized samples, polygonal grains in dynamically recrystallized quartz seams are orientated with their long axes oblique to the main foliation (Fig. 4f). Both relationships indicate a northward overthrust sense of displacement (criteria of Brunel, 1980; Berthé et al., 1979). Feldspar augen in mylonitic samples show asymmetric tails extending along the foliation planes. The vast majority are sigma structures in the terminology of Passchier and Simpson (1986), and indicate northward movement.

\section{Fabrics - Orientation}

Foliation orientations are well clustered within most of the areas represented in individual stereographic plots in Figure 3. Small variations in the mean orientation of foliation from area to area suggest that the foliation in the pluton has been folded in a gentle syncline, with generally southward dips in the north and northward dips farther south. Upright open folds have also affected the unconformably overlying Rapid Brook Conglomerate and Greville River Formation (Donohoe and Wallace, 1985). Anomalous areas immediately west of Refugee Cove, and at the extreme east end of the main outcrop of the pluton show widely dispersed foliations. Field observations at Refugee Cove indicate that this is due to rotational movements of blocks bounded by major steep late faults that mainly dip to the west or southwest.

Within the foliation plane, lineation orientations show considerable variation even between outcrops only a few tens of metres apart. In most areas the trend varies between WNW and NNE, at high angles to regional structural trends and the trace of the Cobequid Fault. Lineations at Little Baldrock Brook and in the Fowler Brook inlier show exceptional SW and WSW tends, roughly parallel to the Cobequid Fault. The significance of the variations is not clear, but they indicate that deformation was not by progressive plane-strain simple shear. One possibility is that there were spatial variations in the direction of movement, perhaps related to inhomogeneities in the pluton. Our field observations indicate that the distribution and orientation of intensely sheared zones was controlled by lithological contrasts between granite and diorite. This is especially true in the less strongly deformed northern part of the pluton, where shear zones tend to follow mafic sheets. Altematively, the observed variation may reflect a progressive temporal change from an initial northward thrusting, to a strike-slip regime that characterizes later movements along the Cobequid fault zone. In this case, the observed scatter of lineations might conceal a number of overprinted generations of structures.

Throughout the areas where lineations trend northeast or southwest, wherever sense of shear can be determined, the sense of transport is hangingwall towards the northwest. In the two anomalous areas of southwest plunging lineation (Little Baldrock and Fowler brooks) the sense is hangingwall northeast.

Faults

Brittle faults are present in all the coastal sections examined, and show a wide variety of orientations. Most common, however, are faults striking between $090^{\circ}$ and $130^{\circ}$ with steep dips to the south (more rarely to the north). Many of these faults downthrow to the south, as indicated by the apparent offset of mafic sheets, and by subsidiary fractures interpreted as synthetic Riedel shears. Others show mineral fibres on fault surfaces indicating significant strike-slip components of movement. Both sinistral and dextral senses have been recorded.

Subhorizontal faults are also common, but are less conspicuous because they generally follow the margins of mafic sheets and the earlier foliation. Sub-horizontal faults cut the margins of dykes at several localities, and show an apparent northward overthrust sense of offset.

We have little evidence of the relative timing of these two sets of faults, but at Carey Brook, a gently-dipping breccia zone that follows a foliated mafic sheet is itself cut by a steep, southwest dipping fault, indicating that the sub-horizontal faults are earlier. We suggest that the steep, south-dipping normal faults, and possibly some strike-slip faults, are related to Mesozoic extension in the Fundy basin. Other strike-slip faults may be related to Carboniferous movements on the Cobequid Fault. The sub-horizontal and gently dipping faults and breccia zones represent a reactivation of the earlier ductile shear zones under brittle 
conditions, or a transition from ductile to brittle deformation during a continuous movement history.

\section{Contacts}

At Seal Cove (Fig. 3), the northern edge of the Cape Chignecto pluton is juxtaposed against basalts and porphyritic rhyolites of the Fountain Lake Group. To the south of the contact (which is not exposed) are granites with south-dipping mafic sheets and discrete south-dipping shear zones. These are cut by unfoliated mafic dykes, which are themselves offset on subhorizontal and south-dipping faults, showing an apparent northward sense of overthrusting. The granites overlie a $6 \mathrm{~m}$ thick sheet of strongly foliated friable mafic phyllites, mylonitic granites and hybrid rocks. Immediately north of the contact are weakly subhorizontally foliated green rhyolites and basalts, locally with tightly folded quartz veins. Farther north, interlayered basalts and rhyolites are unfoliated, but contain southdipping faults with breccia zones. A small inlier centred $0.5 \mathrm{~km}$ north of the contact, shown as granite by Donohoe and Wallace (1982), was found to consist entirely of porphyritic rhyolite.

We interpret these observations to indicate the Cape Chignecto pluton was thrust northward over Fountain Lake Group (Fig. 5). Initial stages in the deformation were ductile and produced localized mylonitic fabrics in granites and mafic phyllites, but later stages (which post-dated dyke intrusion) took place under brittle conditions.

The southern margin of the pluton crops out only in the poorly exposed Fowler Brook inlier, where deformed granite with a south-dipping foliation is overlain by meta-tuff of the Hadrynian Jeffers Group. A thin $(2-3 \mathrm{~cm})$ zone of brecciated granite is present at the contact. Additional outcrops of granite occur to the south, followed by a second contact (well located but not exposed) where foliated granite dips south beneath Jeffers volcanics. These relationships suggest that the two units are interlayered, or that the south-dipping contact is repeated by high-angle faults. The contact is interpreted as an initially ductile thrust (Fig. 5), re-activated as a brittle fault.

\section{AGE RELATIONSHIPS}

The sequence of events in the Cape Chignecto pluton can be partially constrained by the available isotopic and stratigraphic data. A Rb-Sr whole rock isochron of $356 \pm 9$, based on samples showing minimal deformation, is interpreted by Pe-Piper $e t$ al. (in press) as approximating the emplacement age of the pluton; it correlates reasonably with ages from other less deformed plutons of similar composition to the east, and with the extrusive Fountain Lake Group (Cormier, 1982). These plutons are clearly chemically distinct from older, Precambrian intrusions in the western Cobequids (Pe-Piper et al., in press). Green secondary biotite from strongly foliated diorite of the Cape Chignecto Pluton yielded a K-Ar age of $329 \pm 11 \mathrm{Ma}$, which we interpret as approximating the age of ductile deformation. Brown biotite from little-deformed diorite gave a similar $\mathrm{K}$-Ar age of $327 \pm 11$ $\mathrm{Ma}$. (This biotite shows some exsolution of rutile, and has a reduced Ti content compared with biotite from undeformed

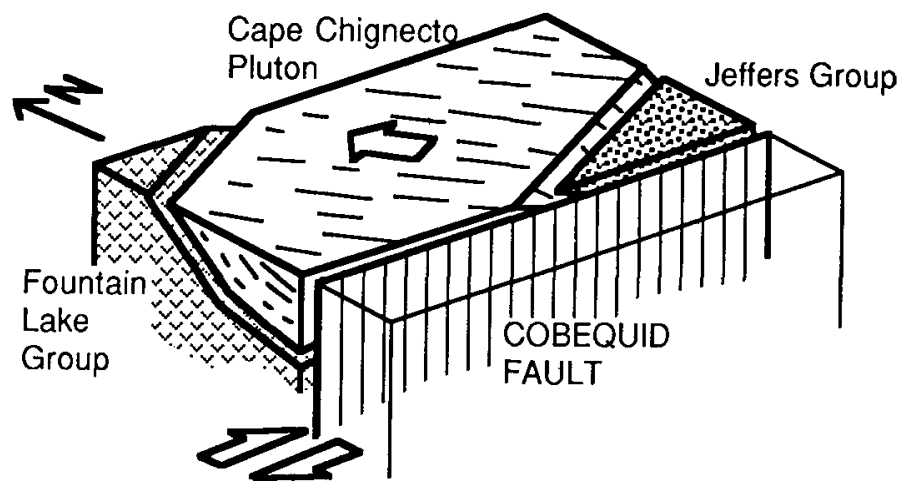

Fig. 5. Schematic block diagram showing inferred geometric and kinematic relationships of tectonic units in Cape Chignecto area. Postpluton sediments and many minor faults omitted.

igneous intrusions, suggesting that it may have been partially or completely reset during deformation.) The predominantly brittle deformation of the feldspars in samples from the pluton suggest that it had cooled to a temperature generally corresponding to greenschist facies before deformation took place (Simpson, 1985), although brittle behaviour of feldspars may occur in amphibolite facies rocks under some strain conditions (J. Hill, personal communication, 1989). Such cooling could occur within two million years of the emplacement of a pluton of this size (Jaeger, 1967).

Stratigraphic control on the age of deformation is provided by the unconformable Rapid Brook and Greville River formations: unfortunately their age of deposition is poorly constrained, but Donohoe and Wallace (1985) proposed that their subsequent deformation was of late Namurian age (about $320 \mathrm{Ma}$ ), although this interpretation is based on correlation of deformational events along the Cobequid Fault. A more definitive mimumum age for the deformation of the pluton, at about $305 \mathrm{Ma}$, is provided by the onlapping Cumberland Group (Donohoe and Wallace, 1985). The hydrothermal event which led to the formation of green biotite in fractures, together with the widespread hematite mineralisation, may be similar in age to an event $45 \mathrm{~km}$ to the east near Parrsboro, isotopically dated by K-Ar on green biotite at $303 \pm 11$ Ma.

\section{DISCUSSION}

Within the broad time framework outlined above, a series of tectonic events can be distinguished. Following intrusion of the Cape Chignecto pluton, probably in the Late Devonian or Early Carboniferous, convergence caused northward thrusting of the Jeffers Group over the pluton, deformation within the pluton, and thrusting of the pluton over the Fountain Lake Group to the north. Later, but possibly as part of a continuous history of deformation, brittle faulting affected the pluton and its boundaries. Initially, ductile shear zones were probably re-activated as thrust faults, but later high-angle faulting occurred along the Cobequid and Kirkhill Fault zones.

The ductile deformation of the Cape Chignecto pluton in the Early Carboniferous predates the major phase of Late Carboniferous thrust deformation in southern New Brunswick by perhaps 
30 million years. It is approximately synchronous with uplift of the Cobequid Highlands on the southern side of Cumberland Basin and of the Caledonia Highlands of southern New Brunswick. This suggests that the Namurian uplift may be associated with a thrusting episode recorded in the Cape Chignecto pluton.

We can envisage several possible regional kinematic histories which would explain the presence of a major zone of overthrust shearing at the extreme western end of the Cobequid Highlands. These can be illustrated by two scenarios (Fig. 6); the actual history may be intermediate between the two. In the first (Fig. 6a) relative movement in Early Carboniferous time between the Avalon and Meguma terrane was constant, parallel to the straight, eastern segment of the present Cobequid - Chedabucto Fault Zone. To the west of Parrsboro, where the Fault Zone curves to the south, oblique convergence occurred. The strikeslip component of the movement was accommodated along a zone parallel to the present Cobequid Fault; the convergent component was accommodated by thrusting in the Cape Chignecto pluton. As the Meguma Terrane was displaced westwards, oblique convergence affected the southern edge of the Avalon Terrane progressively farther west, resulting in the Westphalian deformation in southern New Brunswick.

In the second scenario (Fig. 6b), relative movement varied with time. Initial Carboniferous movement between the Meguma and Avalon Terranes was convergent, and produced a major, NE- striking zone of thrusting within the Avalon Terrane, including the Cape Chignecto pluton. East of the Fowler Brook inlier, this zone is hidden under the later sediments of the Cumberland Basin, although the brittle thrusting seen elsewhere in the westem Cobequid Highlands may be related to this phase of movement. Later, the direction of relative movement changed. The earlier thrust zone was overprinted by brittle strike-slip deformation along the line of the Cobequid Fault, but movement was still obliquely convergent in southem New Brunswick.

\section{CONCLUSIONS}

Ductile deformation of the Cape Chignecto pluton, at the extreme western end of the Cobequid Highlands, took place between about 350 and $320 \mathrm{Ma}$. The deformation resulted from substantial northeast-directed overthrusting, which emplaced the Jeffers Group above the pluton, and the pluton above the Fountain Lake Group. The deformation took place no more than a few tens of million years after the emplacement of the pluton, and was followed by hydrothermal alteration associated with brittle deformation. The thrusting is correlated with Namurian uplift in both the Cobequid and Caledonia Highlands. We interpret the deformation to record an important component of convergence in the relative movement of the Meguma and Avalon terranes.
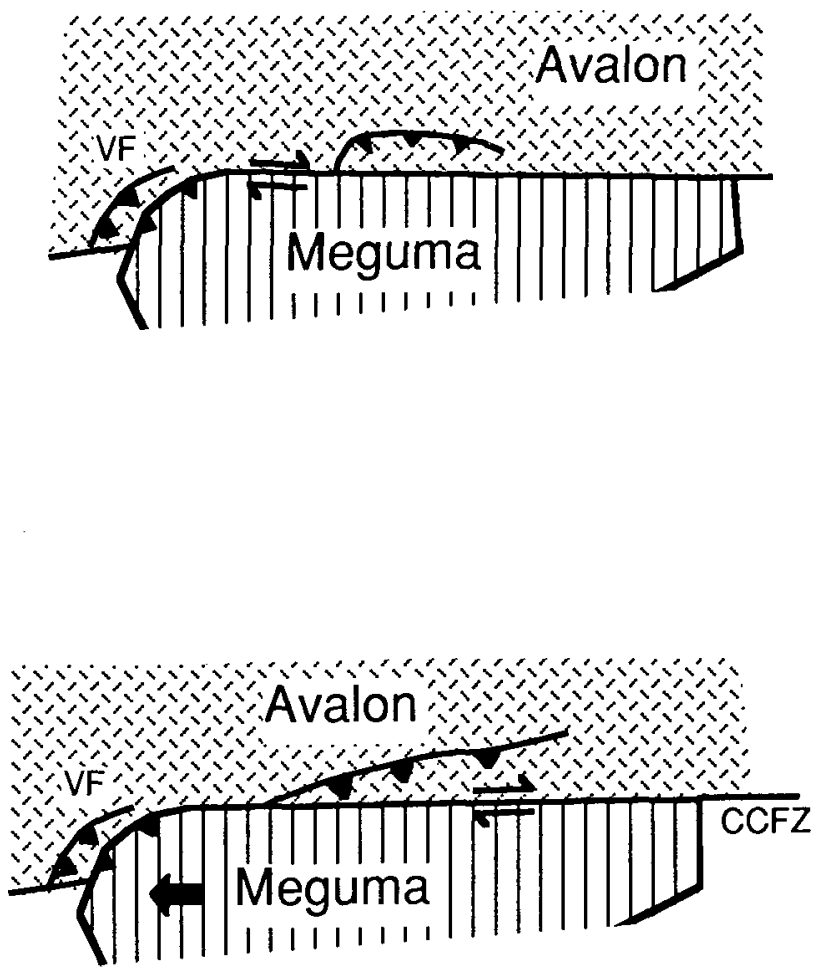

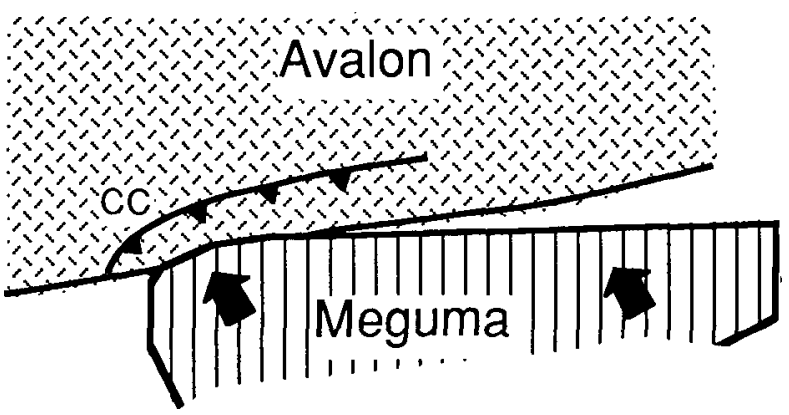

Fig. 6. Kinematic models for Meguma-Avalon interaction during Early Carboniferous. (a) Constant relative movement. Thrusting in Cape Chignecto area (CC) and Variscan Front in southern New Brunswick (VF) is consequence of curvature of Cobequid-Chedabucto Fault Zone (CCFZ). (b) Variable relative movement. Convergent initial movement produces thrust deformation in the Avalon Terrane (Cape Chignecto pluton). Late strikeslip movement along straight portion of Cobequid-Chedabucto Fault Zone truncates thrust belt in western Cobequid Highlands, but causes thrusting along Variscan front in southern New Brunswick. 


\section{ACKNOWLEDGEMENTS}

This work was supported by NSERC operating grants to JWFW and GPP. We thank Denise Turner for assistance in the field. Constructive comments by John Hill and two anonymous referees improved the paper. Geological Survey of Canada contribution number 36788 .

BERTHÉ, D., CHOUKROUNE, P., and JEGOUZO, P. 1979. Orthogneiss, myionite, and non-coaxial deformation of granites: the example of the South Armorican Shear Zone (France). Joumal of Structural Geology, 2, pp. 127-133.

BRUNEL, M. 1980. Quartz fabric in shear zone mylonites; evidence for a major imprint due to late strain increments. Tectonophysics, 64 , pp. 133-144.

CORMIER, R.F. 1979. Rubidium/strontium isochron ages of Nova Scotia granitoid plutons. Nova Scotia Department of Mines and Energy, Report 79-1, pp. 143-148.

- 1982. Rb/Sr age data for the Fountain Lake Group Volcanics. Report of Activities, Nova Scotia Department of Mines and Energy, Report 82-1, pp. 114-115.

DONOHOE, H.V., HALLIDAY, A.N., and KEPPIE, J.D. 1986. Two Rb-Sr whole rock isochrons from plutons in the Cobequid Highlands, Nova Scotia, Canada. Maritime Sediments and Atlantic Geology, 22, pp. 148-154.

DONOHOE, H.V. and WALLACE, P.I. 1982. Geological map of the Cobequid Highlands, Nova Scotia. Scale 1:50,000. Nova Scotia Department of Mines and Energy.

. 1985. Repeated orogeny, faulting and stratigraphy in the Cobequid Highlands, Avalon Terrain of northern Nova Scotia. Geological Association of Canada - Mineralogical Association of Canada, Joint Annual Meeting, Fredericton, New Brunswick, Excursion Guide 3, 77 p.

EISBACHER, G.H. 1969. Displacement and stress field along part of the Cobequid Fault, Nova Scotia. Canadian Journal of Earth Sciences, 6, pp. 1095-1104.

- 1970. Deformation mechanisms of mylonitic rocks and fractured granites in the Cobequid Mountains, Nova Scotia, Canada. Geological Society of America Bulletin, 81, pp. 2009-2020.

HUTCHINSON, D.R., KLITGORD, K.D., and TREHU, A.M. 1988.
U.S. Geological Survey deep seismic reflection profile across the Gulf of Maine. Geological Society of America Bulletin, 100, pp. 172-184.

JAEGER, J.C. 1967. Cooling and solidification of igneous rocks. In Basalts. Edited by H. Hess and A.P. Poldervaart. Interscience Publishers, 2, pp. 506-536.

KEPPIE, J.D. 1982. The Minas geofracture. In Major structural zones and faults of the Northern Appalachians. Edited by P. St. Julien and J.Beland. Geological Association of Canada, Special Paper 24, pp. 263-280.

MAWER, C.K. and WHITE, J.C. 1987. Sense of displacement on the Cobequid - Chedabucto fault system, Nova Scotia, Canada. Canadian Journal of Earth Sciences, 24, pp. 217-223.

MAWER, C.K. and WILLIAMS, P.F. 1986. Structural study of highly deformed Meguma phyllite and granite, vicinity of White Head village, SE Nova Scotia. Maritime Sediments and Atlantic Geology, 22, pp. 51-64.

NANCE, R.D. and WARNER, J.B. 1987. Variscan tectonostratigraphy of the Mispec Group, southern New Brunswick: structural geometry and deformational history. Geological Survey of Canada, Paper 87-1, pp. 351-358.

PASSCHIER, C.W. and SIMPSON, C. 1986. Porphyroclast systems as kinematic indicators. Joumal of Structural Geology, 8, pp. 831843.

PE-PIPER, G., CORMIER, R.F., and PIPER, D.J.W. In press. The age and significance of Carboniferous plutons of the Westem Cobequid Hills, Nova Scotia. Canadian Journal of Earth Sciences.

PLINT, A.G. and VAN DE POLL, H.W. 1984. Structural and sedimentary history of the Quaco Head area, southern New Brunswick. Canadian Journal of Earth Sciences, 21, pp. 753-761.

RYAN, R.J., CALDER, J.H., and NAYLOR, R. 1987. Late Paleozoic sedimentation and basin development adjacent to the Cobequid Highlands massif, eastem Canada. Canadian Society of Petroleum Geologists, Memoir 12, pp. 311-317.

SIMPSON, C. 1985. Deformation of granite across the brittle-ductile transition. Journal of Structural Geology, 7, pp. 503-511.

WILLIAMS, H. and HATCHER, R.D. 1983. Appalachian suspect terraines. Geological Society of America, Memoir 158, pp. 33-53.

YEO, G. and GAO, R.-X. 1987. Stellarton graben: an upper Carboniferous pull-apart basin in northem Nova Scotia. Canadian Society of Petroleum Geologists, Memoir 12, pp. 299-309. 